\title{
A Comparative Feasibility Study of Stand-Alone and Grid-Connected PV System for Residential Load: A Case Study in Iran
}

\author{
Navid Hadifar ${ }^{1, *}$, Amirreza Ayanlou ${ }^{2}$ \\ ${ }^{1}$ Department of Astronautical, Electrical and Energy Engineering (DIAEE) Sapienza University of \\ Rome, Via delle Sette Sale, 00184, Rome, Italy \\ ${ }^{2}$ Department of Astronautical, Electrical and Energy Engineering (DIAEE) Sapienza University of \\ Rome, Via delle Sette Sale, 00184, Rome, Italy
}

\begin{abstract}
With rising the environmental issues regarding the fossil fuels, the renewable energy resources (RES) could be as interesting scheme in supply side for micro grids. The aim of this paper is to investigate the feasibility of photovoltaic (PV) system in Iran both in grid-connected and island mode. The case study is a residential house in the city of Amol. The software of HOMER (Hybrid Optimization of Multiple Energy Resources) is used for analyzing the data for finding the optimal design among the various solutions which takes in to account electrical and economic assessment factors. In the section of grid-connection mode, two different simulation methods namely HOMER optimizer mode and optimal sizing design mode is used to better understand the grid participation with PV in supplying the power for load demand. Finally, the optimal and affordable design for selected region is grid-connected PV system which alleviate the energy need from grid.
\end{abstract}

\section{Introduction}

These days, due to the global warming and environmental issues of using fossil fuels, RES can play dominant role for supplying the energy demand in the world. Also, with having growth in population, the need for more energy is undeniable fact which causes to accelerate the depletion of fossil fuels resources. Lior [1] investigated that with this amount of energy consumption in the world, the fossil fuels resources will be ended at the end of this century. Nurunnabi et al [2] found that Among the RES, the PV system could be more interesting for global energy market due to the low initial cost in compare with other RES and potential benefits in countries.

The aim of this study is to investigate the feasibility of using and developing the PV system as source of RE for providing the sustainable and reliable electricity supplies for residential load in Iran. Samimi [3] studied the potential of solar irradiation in Iran and reached that this country possesses desirable condition in using solar energy. Thus, supplying the load demand from PV system could be beneficial solution for alleviating the dependency to the fossil fuels [4]. According to this, a residential house in Amol city of Mazandaran province has been selected as sample which possess the relatively high amount of solar radiation. In addition, all assumption regarding the load consumption has been based on moderate family in terms of consumption. For achieving the optimal RES design, different companies have built computer software's for modelling and analyzing the behavior of

*Corresponding author: navidhadifar1992@gmail.com 
proposed systems in terms of electrical and economical aspect. The HOMER is one of those software's which is used by RE planners to obtain ideal system among the different feasibility study solutions [5].

In this paper, both grid-connected and island mode has been simulated and examined from technical and economical aspect by HOMER software. Also, in the section of gridconnected, for sizing the optimal PV system, two different modes of this software namely HOMER optimizer design and optimal sizing design has been carried out. This paper is arranged as follows: Section 2 explains the PV system components. Problem Formulation and Description discusses in section 3. The HOMER Simulation and Results is given in section 4 and finally section 5 presents the conclusion.

\section{PV system components}

PV systems can be divided into three main parts as PV panels, Optimal Power Generation or Control Section and the electrical load. PV panels are part of the solar energy converters which converting the solar energies to electricity without mechanical intermediation. Optimal Power Generation or Control Section is responsible for controlling all the system and consists of several parts including battery energy storage system (BESS), charge control, MPPT and inverter which the application of each equipment is depend on the consumer's specifications and needs [6]. The Consumer or Electric load which can be in two types of DC or AC load. The electrical load in this case study is in AC type [7].

\subsection{PV panel}

Sun can have dominant role in production of energy from renewable resources. The amount of solar radiation fluctuates around the world and is the highest in the Earth's solar belt. Iran has located in the area which possess highest amount of irradiation, and researches show that the use of PV system in this region is appropriate and can provide part of the energy demands [8]. Amol city in Mazandaran province of Iran has been chosen with the geographical position of $36^{\circ} 28^{\prime} 15^{\prime \prime}$ North, $52^{\circ} 21^{\prime} 48^{\prime \prime}$ East. Owing to its mild and humid climate, Amol provides relatively high amount of solar energy. The curve and chart of Fig. 1 represents the clearness index and the amount of solar irradiance respectively during the year in monthly way for Amol. This information was extracted from NASA meteorological database.

Looking to the figure.1. the trend of solar irradiance curve is in increasing form which reaches to $6.15 \mathrm{kWh} / \mathrm{m}^{2} /$ day for the month of June and then possess declined behavior and reaches to the lowest level in December which is $1.8 \mathrm{kWh} / \mathrm{m}^{2} /$ day.

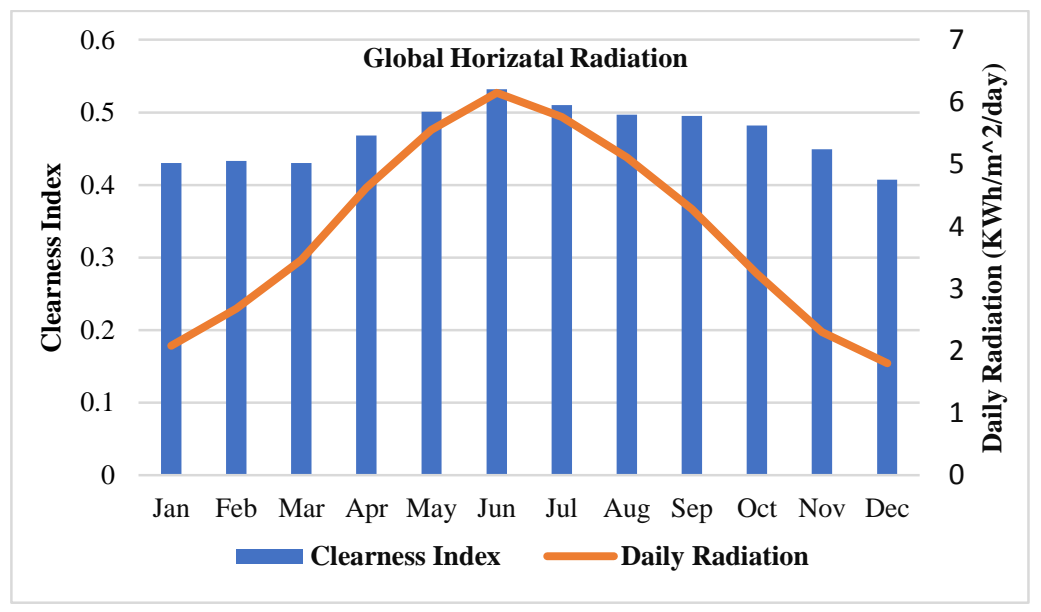


Fig. 1. The clearness index and the daily radiation of solar for Amol.

For calculating the needed surface area for the PV panel, the following Eq. (1) can be written. The APV is defined as the desirable surface of panel in $\mathrm{m}^{2}$, electric load is shown by $\mathrm{L}_{\mathrm{el}}$ in the unit of $\mathrm{kWhd}^{-1}, \mathrm{IR}_{\mathrm{av}}$ is the average irradiation available per day in $\mathrm{kWh} / \mathrm{m}^{2} /$ day. $\eta_{\text {panel }}, \eta_{\text {battery }}$ and $\eta_{\text {inverter }}$ states their efficiencies in $\%$. The correction factor of temperature is stated by $\mathrm{T}_{\mathrm{CF}}$ which considers as $-0.3 \%$ per ${ }^{\circ} \mathrm{C}$ for monocrystalline cells. [9]:

$$
A_{P V}=\frac{L_{e l}}{I R_{a v} \times T_{C F} \times \eta_{\text {panel }} \times \eta_{\text {inverter }} \times \eta_{\text {battery }}}
$$

In addition, the maximum amount of panel power $\left(\mathrm{P}_{\max (\mathrm{Panel})}\right)$ can be presented in Eq. (2), where $\mathrm{IR}_{\max }$ is the maximum amount of solar irradiation which assumes as $1000 \mathrm{Wm}^{-2}$ [10].

$$
P_{\max (\text { panel })}=A_{P V} \times I R_{\max } \times \eta_{P V}
$$

For required characteristics information, a datasheet regarding the PV panels is essential. Hence, the capital and replacement costs for 1kW PV system is taken \$300 USD for each of them. The maintenance cost is nearly $\$ 25$ for the PV system. The technical specifications have represented in Table 1.

Table 1. Detail of PV panel.

\begin{tabular}{|c|c|}
\hline Rated power (Watt) & 335 \\
\hline Operating temperature (C) & 43 \\
\hline Efficiency of panel (\%) & 21 \\
\hline Voltage Rate (Vmpp) & 57.3 \\
\hline Current Rate (Impp) & 5.85 \\
\hline
\end{tabular}

\subsection{BESS}

In case of using an off-grid PV power plant, it would be essential to use BESS. Since, this component as a storage device saves the electricity production by PV panel during the day and supplies the required electrical load. For setting the capacity of BESS, in the first step, the amount of energy consumption per day should be known. Then, with having the efficiency, independent days, the period of BESS utilization in each day and the limit of the depth of discharge amounts, the needed amount can be achieved as Eq. (3) [11].

$$
\text { Capacity of Battery }=\frac{\text { Energy per day } \times \text { Independent day }}{\text { Efficiency } \times \text { DoD limit } \times \text { Battery consumption }}
$$

In this paper solar BESS is considered, as they have superior performance and longer lifetime (10 years). The BESS considered with nominal voltage of $220 \mathrm{~V}$. The capital and replacement cost of each BESS is taken $\$ 125$, separately. Other specific information has been shown in Table 2.

Table 2. Detail of BESS.

Nominal capacity $(\mathrm{kWh})$ 


\begin{tabular}{|l|l|}
\hline Nominal capacity (Ah) & 62 \\
\hline Efficiency (\%) & 0.89 \\
\hline Maximum charge current (A) & 31.8 \\
\hline Maximum discharge current(A) & 31.8 \\
\hline
\end{tabular}

\subsection{Converter (Inverter/Charger)}

The converters are converting AC to DC power and conversely. Thus, in proposed model, it would be vital to convert DC voltage which is generated by PV panel and BESS for supplying the AC load. The capital cost of inverter is taken $\$ 200$ and the replacement cost is the same. The cost of operation and maintenance is zero. The inverter's efficiency considers $93 \%$ and lifetime is supposed for 10 years.

\subsection{Load profile}

The estimation of AC load consumption would cause to have well designed system which is closer to the reality. Since, the noticeable percentage of Iranian living in urban areas, have moderate electricity usage. The house which have 5 inhabitants, is assumed with moderate energy consumption. The data regarding the load consumption has been gathered from hourly load seeing of the house in 24-hour period during day. According to the habits of Iranian families, the load profile has been classified in four seasons which represents the different amount of load usage for seasons of a year as winter, spring, summer and autumn during the day [12].

The monthly load profiles are shown in the Table 3 . The charts in this table show that in June from $16 \mathrm{pm}$ up to $19 \mathrm{pm}$, there is high maximum demand for load in this month because of using the air condition system for cooling. On the other hand, in December from $20 \mathrm{pm}$ up to $22 \mathrm{pm}$, the usage of heating air condition system has been impressed the load profile.

Table 3. The load profile of electricity consumption.

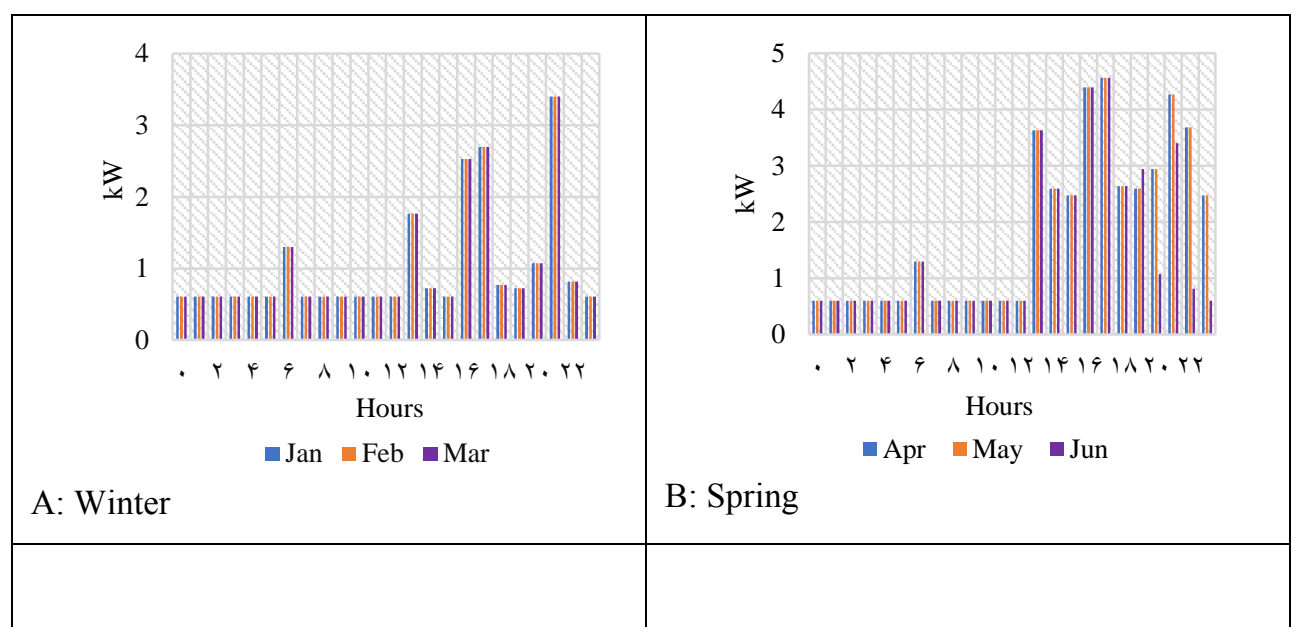




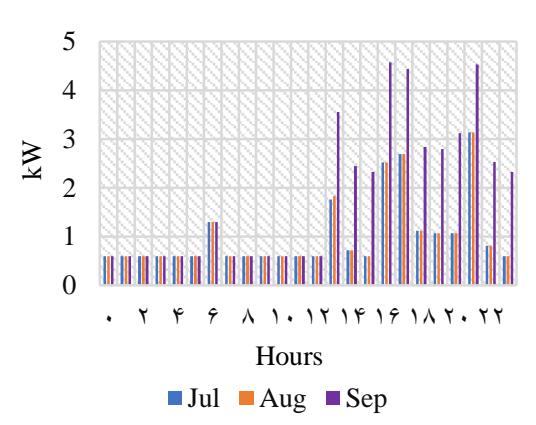

C: Summer

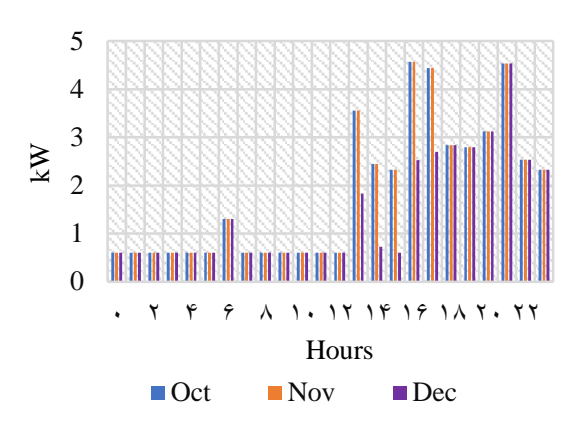

D: Autumn

\section{Problem formulation and description}

\subsection{Description of optimizing and sensitivity analysis by HOMER software}

HOMER software is the distributed generation and micro grid modeling software which provides best solution for designing the qualified micro grid in terms of economic and technical aspect with processing the different factors such as load management, cost of components, storage and generated energy. It makes possible to examine various technology procedures to consider for available energy resource with different options. The flowchart in Fig.2 shows the structure of optimization and analyzing the sensitivity in HOMER software [13].

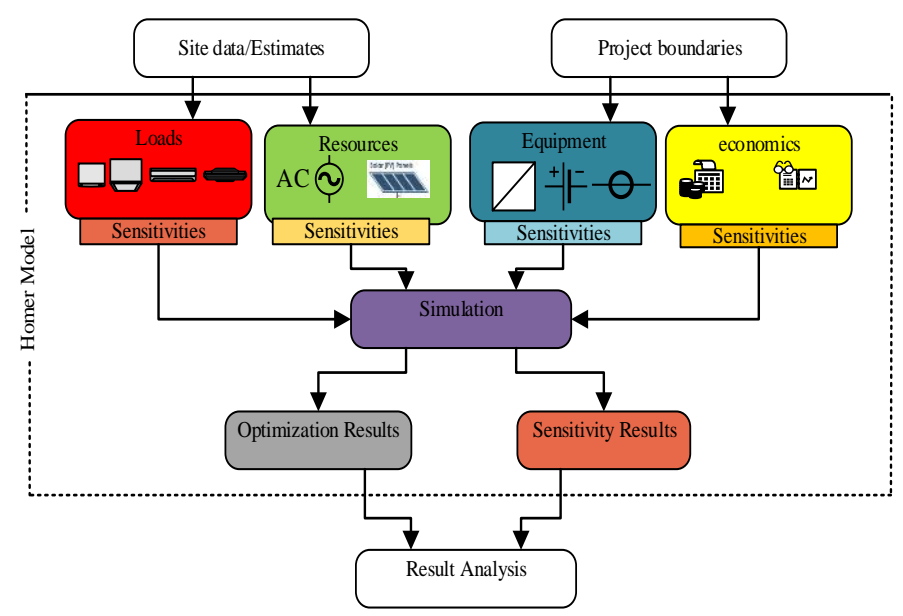

Fig. 2. Optimization and sensitivity analysis flowchart in HOMER software.

\subsection{Cost Analysis Procedure by HOMER}

The total net present cost (NPC) and the leveled cost of energy (COE), which are the two main economic elements, depend on the total annualized cost of the system. Since, the consumer needs to calculate the annualized costs of the system, which represented as the components' annualized cost minus any miscellaneous costs. The total NPC is stated by Eq. (4), where $\mathrm{C}_{\text {TANN }}$ is the total annualized cost, $\mathrm{i}$ is the annual real interest rate, $\mathrm{N}$ is the number of years, $\mathrm{CRF}_{(\mathrm{i}, \mathrm{N})}$ is the capital recovery factor, and it is calculated as Eq. (5) [14]. 


$$
\begin{gathered}
C_{N P C}=\frac{C_{T A N N}}{C R F_{(i, N)}} \\
C R F_{(i, N)}=\frac{i(1+i)^{N}}{(1+i)^{N-1}}
\end{gathered}
$$

In addition, the COE can be stated as the average cost per $\mathrm{kWh}$ of the production of electrical energy used by the system. The Eq. (6) is used to calculate the levelized COE. In this equation, $\mathrm{E}_{\mathrm{Is}}$ is the electrical energy that the microgrid system serves and $\mathrm{E}_{\text {grid }}$ is the value of electricity sold to the grid by microgrid.

$$
C O E=\frac{C_{T A N N}}{E_{I S}+E_{\text {grid }}}
$$

In the following, the amount of electricity sold to the grid by microgrid is added in the levelized COE equation. In HOMER, the total NPC is the economically preferred element and has been applied in the optimization procedure, not the levelized COE, because each of these decisions is somewhat optional [15].

The salvage value Can be defined as remaining value of the system components at the end of project life which has been shown by Eq. (7), where $S$ is allocated to the salvage value, $\mathrm{C}_{\text {rep }}$ is stated by the replacement cost of the component, $\mathrm{R}_{\text {rem }}$ is the remaining life of the component and $\mathrm{R}_{\text {comp }}$ is the lifetime of the component in proposes system [16].

$$
S=C_{\text {rep }} R_{\text {rem }} / R_{\text {comp }}
$$

\section{HOMER Simulation and Results}

The results have been investigated in two different scenarios. For the first scenario, the simulation analysis for PV system has been done on grid-connected mode. Also, island mode which has based on HOMER optimizer for finding the optimal sensitivity amounts of the equipment has been investigated in the second scenario.

\subsection{Grid-connected mode}

A PV array and grid-connected inverter were modelled with the connection to electricity network. The behavior of system when is connected to the grid has been shown in Table 4 . It should be noticed that in all cases, the maximum exchange power by grid is $5 \mathrm{~kW}$. Due to proximity to the utility grid, use of the BESS has been neglected to reduce system costs.

Table 4. The system behavior in grid-connected mode.

\begin{tabular}{|c|}
\hline $\mathrm{P}_{\mathrm{PV}}=\mathrm{P}_{\mathrm{Load}} \rightarrow$ Balance mode \\
\hline $\mathrm{P}_{\mathrm{PV}}>\mathrm{P}_{\mathrm{Load}} \rightarrow$ Excess power sells to grid \\
\hline $\mathrm{P}_{\mathrm{PV}}<\mathrm{P}_{\text {Load }} \rightarrow$ The required power receives from \\
grid
\end{tabular}


Fig. 3 is the schematic diagram of the proposed PV system with the electricity network. The design of system has been based on two operation modes which for the first mode, the HOMER simulation is on optimizer mode and for the other, the optimal sizing of PV panel has been considered.

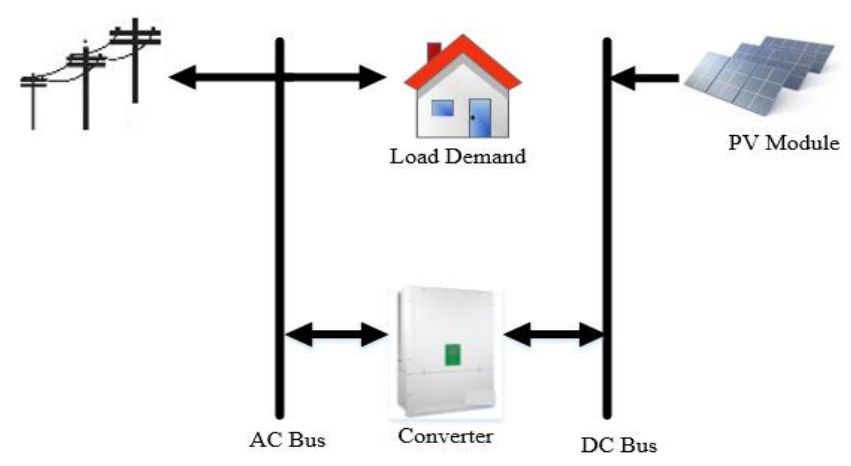

Fig. 3. Grid-Connected PV system.

The cost of power generation in Iran is around $0.05 \$ / \mathrm{kWh}[17]$. By comparing the cost of demand which has been shown in the Table 5. There is huge gap between the cost of demand and the cost of generation (the cost of generation is nearly 10 times of the cost of demand).

Table 5. The rate definition of Grid.

\begin{tabular}{|l|l|}
\hline Load Period & Price $(\$ / \mathrm{kWh})$ \\
\hline Peak & 0.0130 \\
\hline Shoulder peak & 0.0050 \\
\hline Off peak & 0.0030 \\
\hline
\end{tabular}

\subsubsection{HOMER optimizer mode}

The system is analyzed in HOMER software based on the optimum of the capacity of PV panels in the range of $\mathrm{kW}$ with considering HOMER optimizer variables and economic constrains like interest rate, minimum renewable fraction, capacity shortage and other factors. The optimized model has been stated in table 6 [18]. 
Table 6. Optimized simulation results from HOMER.

\begin{tabular}{|c|c|c|c|c|c|c|c|}
\hline \multicolumn{2}{|c|}{ Architecture } & \multicolumn{4}{c|}{ Cost (\$) } & \multicolumn{2}{c|}{ PV module } \\
\hline $\begin{array}{c}\text { PV } \\
\text { module } \\
\text { (quantity) }\end{array}$ & $\begin{array}{c}\text { Converter } \\
\text { (quantity) }\end{array}$ & NPC & COE & $\begin{array}{c}\text { Opera } \\
\text { ting } \\
\text { cost }\end{array}$ & $\begin{array}{c}\text { Initial } \\
\text { capital }\end{array}$ & $\begin{array}{c}\text { Capital } \\
\text { cost } \\
(\$)\end{array}$ & $\begin{array}{c}\text { Production } \\
(\mathrm{kWh} / \mathrm{yr})\end{array}$ \\
\hline 1 & 1 & 354.92 & 0.00668 & 27.38 & 0.915 & 0.704 & 3.19 \\
\hline
\end{tabular}

Simulation result shows that the AC primary load is $4109 \mathrm{kWh} / \mathrm{yr}$, and the excess electricity is $0.548 \mathrm{kWh} / \mathrm{yr}$ and unmet electric load is zero. The power demand supplied by the PV system which has been obtained by software is $3.19 \mathrm{kWh} / \mathrm{yr}$. The result shows that $99.9 \%$ of electricity demand is supplied by power grid and only $0.07 \%$ is taken from PV panel.

For showing the behavior of designed system, one week of the month of December (from 20 to 26 of December) has been selected to better evaluating the system operation. Since, this month has lowest solar radiation during the year for this case study. The behavior of designed system has shown in Fig.4 which shows the participation of PV panel is very insignificant in compare with grid purchased electricity [19]. Due to the inequality in supplying power from grid and PV which results show the poor share of PV in represented case, the different range of PV has been arranged in the section 4.2 for finding the optimal balance for supplying the load between grid and PV. It should be noticed that the horizontal axis in chart of Fig. 4 shows the 168 hours of one week in selected period.

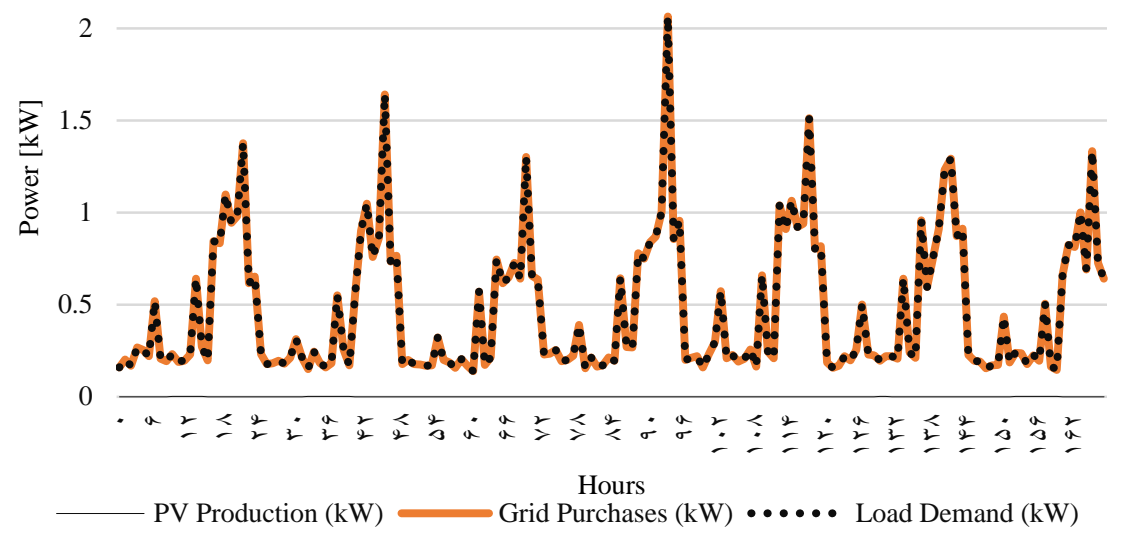

Fig. 4. The curve of system's operation in terms of power sources for optimizer mode

The project lifetime is 25 years and the real interest rate is taken as $5.88 \%$. No fixed operation and maintenance costs are considered as they are given in the individual components except of PV panels. Annual capacity shortage is set to zero. The NPC cash flow summary is given in Table 7.

Table 7. NPC summary of the proposed system. 


\begin{tabular}{|c|c|c|c|c|c|}
\hline \multicolumn{7}{|c|}{ NPC for each component (\$) } \\
\hline Component & Capital & Replacement & O \&M & Salvage & Total \\
\hline Grid & 0.00 & 0.00 & 352.98 & 0.00 & 352.98 \\
\hline Converter & 0.212 & 0.187 & 0.00 & -0.0254 & 0.373 \\
\hline PV panel & 0.704 & 0.224 & 0.758 & -0.126 & 1.56 \\
\hline System & 0.915 & 0.411 & 353.77 & -0.152 & 354.92 \\
\hline
\end{tabular}

The main economic output in the PV power plant system in HOMER is present total net cost. HOMER calculates the data output from simulation and NPC optimization. In this section, the NPC is $\$ 354.95$. Therefore, with connecting grid to the proposed system and due to the low price of electricity production in Iran, applying of PV panel is unreasonable. The results of simulation for each component has been shown in Table 8 .

Table 8. Simulation results for PV system in Grid-connected system.

\begin{tabular}{|c|c|c|c|c|c|}
\hline \multicolumn{2}{|c|}{ PV panel } & \multicolumn{4}{c|}{ Converter } \\
\hline Quantity & Value & Quantity & Inverter & Rectifier & Units \\
\hline Rated Capacity & $0.002 \mathrm{~kW}$ & Capacity & 0.0010 & 0.0009 & $\mathrm{~kW}$ \\
\hline Mean Output & $0.0003 \mathrm{~kW}$ & Energy out & 2.46 & 0 & $\mathrm{kWh} /$ year \\
\hline Mean Output & $\begin{array}{c}0.008 \\
\mathrm{kWh} / \mathrm{d}\end{array}$ & Energy in & 2.65 & 0 & $\mathrm{kWh} /$ year \\
\hline Total Production & $\begin{array}{c}3.19 \\
\mathrm{kWh} / \mathrm{yr}\end{array}$ & Losses & 0.185 & 0 & $\mathrm{kWh} /$ year \\
\hline Hours of Operation & $\begin{array}{c}4,386 \\
\mathrm{hrs} / \mathrm{year}\end{array}$ & $\begin{array}{c}\text { Hours of } \\
\text { operation }\end{array}$ & 3,751 & 0 & $\mathrm{hrs} /$ year \\
\hline
\end{tabular}

\subsubsection{Optimal sizing design}

In this section, for ideal exchange of power between the micro grid and the power grid, three different PV panel power ranges between $1 \mathrm{~kW}$ to $3 \mathrm{~kW}$ are examined to select the best PV panel power range for this project by comparing the results. The system is analyzed in HOMER software based on various sensitivity variables and economic assessment factors. Table 9. shows the optimization results for the grid-connected PV power system with the panels of 1,2 and $3 \mathrm{~kW}$. 
Table 9. Optimized simulation results from HOMER.

\begin{tabular}{|c|c|c|c|c|c|c|c|c|}
\hline \multicolumn{3}{|c|}{ Architecture } & \multicolumn{5}{c|}{ Cost (\$) } & \multicolumn{2}{c|}{ PV module } \\
\hline $\begin{array}{c}\text { PV } \\
\text { module } \\
(\mathrm{kW})\end{array}$ & $\begin{array}{c}\text { Grid } \\
(\mathrm{kW})\end{array}$ & $\begin{array}{c}\text { Converter } \\
(\mathrm{kW})\end{array}$ & NPC & COE & $\begin{array}{c}\text { Operating } \\
\text { cost }\end{array}$ & $\begin{array}{c}\text { Initial } \\
\text { capital }\end{array}$ & $\begin{array}{c}\text { Capital } \\
\text { cost } \\
(\$)\end{array}$ & $\begin{array}{c}\text { Production } \\
(\mathrm{kWh} / \mathrm{yr})\end{array}$ \\
\hline 1 & 2.5 & 0.604 & 922.03 & 0.0157 & 38.77 & 420.83 & 300 & 1362 \\
\hline 2 & 2.21 & 1.24 & 1219 & 0.0174 & 28.73 & 847.92 & 600 & 2724 \\
\hline 3 & 2.08 & 1.88 & 1434 & 0.0172 & 12.29 & 1275 & 900 & 4087 \\
\hline
\end{tabular}

With increasing the capacity of PV panel from 1 up to $3 \mathrm{KW}$, the share of PV panel in electricity production is achieved according Table 10. It is obvious that the amount of electricity production has been increased with increasing the capacity of PV panel. Furthermore, the other electrical specification has been attached to this table. There is no unmet electric load and capacity shortage is zero.

Table 10. The percent of electricity production by PV.

\begin{tabular}{|c|c|c|c|c|c|c|}
\hline \multirow{2}{*}{$\begin{array}{c}\text { PV } \\
\text { panel } \\
(\mathrm{kW})\end{array}$} & \multicolumn{2}{|c|}{ PV Production } & \multicolumn{2}{|c|}{ Grid purchases } & \multirow{2}{*}{$\begin{array}{l}\text { Excess } \\
\text { electricity } \\
(\mathrm{kWh} / \mathrm{yr})\end{array}$} & \multirow{2}{*}{$\begin{array}{l}\text { Renewable } \\
\text { fraction } \\
(\%)\end{array}$} \\
\hline & $\begin{array}{c}\text { Percent } \\
(\%)\end{array}$ & $(\mathrm{kWh} / \mathrm{yr})$ & $\begin{array}{c}\text { Percent } \\
(\%)\end{array}$ & $(\mathrm{kWh} / \mathrm{yr})$ & & \\
\hline 1 & $29^{\circ}$ & 1362 & 71 & 3333 & 76.7 & 26.4 \\
\hline 2 & 47.5 & 2724 & 52.5 & 3016 & 134 & 44.4 \\
\hline 3 & 59 & 4087 & 41 & 2843 & 192 & 56.0 \\
\hline
\end{tabular}

From the perspective of PV panel participation, it is observed that by increasing the panel capacity from $1 \mathrm{~kW}$ to $2 \mathrm{~kW}$, the panel contribution will increase by nearly $20 \%$, while by increasing the capacity from $2 \mathrm{~kW}$ to $3 \mathrm{~kW}$, the share of panel participation in simulation will increase approximately $11 \%$. On the other hand, there is not much more load peak demand during the day. According to the Table. 9, by comparing the capital costs and the amount of power production by panels, with gaining the capacity of panels, the amount of power production is doubled when it rises from $1 \mathrm{~kW}$ to $2 \mathrm{~kW}$. But with the amount of increment in panel capacity from $2 \mathrm{~kW}$ to $3 \mathrm{~kW}$, the amount of increase reaches to the $33 \%$. Consequently, it can be concluded that from both electrical and economical aspect the panel of $2 \mathrm{~kW}$ is more reasonable and used for the simulation procedure in direct of meeting energy balance. All economic aspects for the selected panel such as COE and NPC have been referred in Table 9.

The monthly electrical production graph has been represented in Fig.5. The maximum power is taken from grid belongs to the June and December is the lowest month which has got power from grid. 


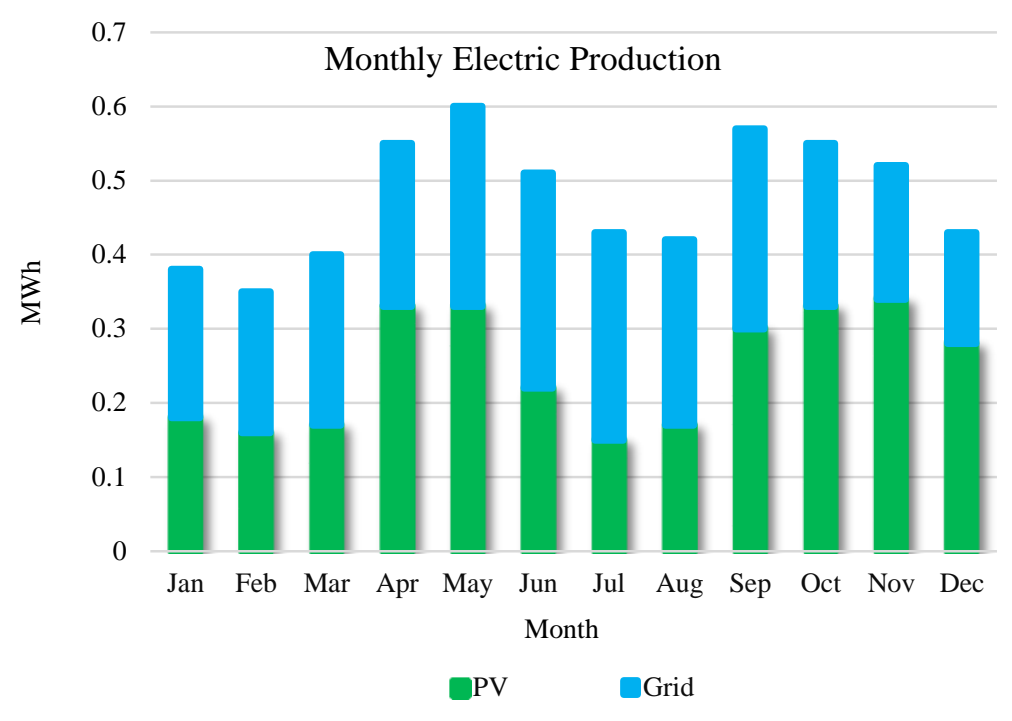

Fig. 5. The monthly average electric power produced by PV system.

The relation between designed system for power production and power demand for the period of 20 to 26 December has been represented in Fig.6. By looking to the plot, it can be evaluated that whenever the PV production is going to be zero due to the worse climate, the grid act as reserve source and supply the power demand.

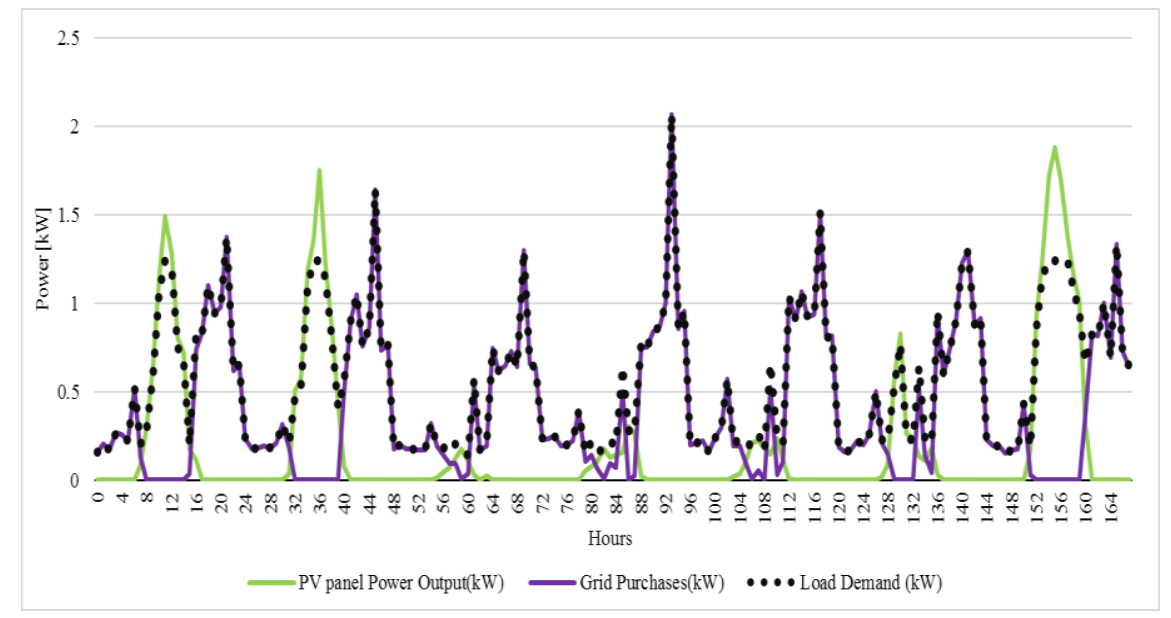

Fig. 6. The curve of system's operation in terms of power sources in optimal mode.

The NPC summary according to each component is given in Table 11.

Table 11. NPC summary of the proposed system.

\begin{tabular}{|c|c|c|c|c|c|}
\hline \multicolumn{5}{|c|}{ NPC for each component (\$) } \\
\hline Component & Capital & Replacement & O \&M & Salvage & Total \\
\hline Grid & 0.00 & 0.00 & 573.58 & 0.00 & 573.58 \\
\hline
\end{tabular}




\begin{tabular}{|c|c|c|c|c|c|}
\hline Converter & 247.92 & 219.02 & 0.00 & -29.70 & 437.24 \\
\hline PV panel & 600 & 191.28 & 646.38 & -107.80 & $1,329.86$ \\
\hline System & 847.92 & 410.30 & 72.79 & -137.50 & $1,193.52$ \\
\hline
\end{tabular}
12.

The technical detail of grid-PV system for different components has been stated in Table

Table 12. Simulation results for PV system in grid-connected mode.

\begin{tabular}{|c|c|c|c|c|c|}
\hline \multicolumn{2}{|c|}{ PV panel } & \multicolumn{4}{|c|}{ Converter } \\
\hline Quantity & Value & Quantity & Inverter & Rectifier & Units \\
\hline $\begin{array}{l}\text { Rated } \\
\text { Capacity }\end{array}$ & $2 \mathrm{~kW}$ & Capacity & 1.24 & 1.99 & $\mathrm{~kW}$ \\
\hline $\begin{array}{l}\text { Mean } \\
\text { Output }\end{array}$ & $\begin{array}{c}0.013 \\
\mathrm{~kW}\end{array}$ & $\begin{array}{c}\text { Energy } \\
\text { out }\end{array}$ & 2,409 & 0 & $\mathrm{kWh} /$ year \\
\hline $\begin{array}{l}\text { Mean } \\
\text { Output }\end{array}$ & $\begin{array}{c}7.46 \\
\mathrm{kWh} / \mathrm{d}\end{array}$ & $\begin{array}{c}\text { Energy } \\
\text { in }\end{array}$ & 2,590 & 0 & $\mathrm{kWh} /$ year \\
\hline $\begin{array}{c}\text { Total } \\
\text { Production }\end{array}$ & $\begin{array}{c}2,724 \\
\mathrm{kWh} / \mathrm{yr}\end{array}$ & Losses & 181 & 0 & $\mathrm{kWh} /$ year \\
\hline $\begin{array}{l}\text { Hours of } \\
\text { Operation }\end{array}$ & $\begin{array}{c}4,386 \\
\text { hrs/year }\end{array}$ & $\begin{array}{l}\text { Hours of } \\
\text { operation }\end{array}$ & 4,386 & 0 & hrs/year \\
\hline
\end{tabular}

\subsection{Island mode operation}

The system is designed to supply the AC load by PV panel which in case of having excess PV production, this amount of power is charged into the BESS. On the other side, while the AC load is much more than the PV production, the BESS will provide the power [20]. The behavior of system in different modes has been shown in Table 13 [21].

Table 13. The system behavior in island mode.

\begin{tabular}{c}
\hline $\mathrm{P}_{\mathrm{PV}}=\mathrm{P}_{\text {Load }} \rightarrow$ Balance mode \\
\hline $\mathrm{P}_{\mathrm{PV}}>\mathrm{P}_{\text {Load }} \rightarrow$ BESS in charging mode \\
\hline $\mathrm{P}_{\mathrm{PV}}<\mathrm{P}_{\text {Load }} \rightarrow$ BESS in discharging mode \\
\hline
\end{tabular}

The structure of system in the simulation consists of four components, namely, PV, bidirectional AC/DC converter, BESS, and AC load, as presented in Fig.7. 


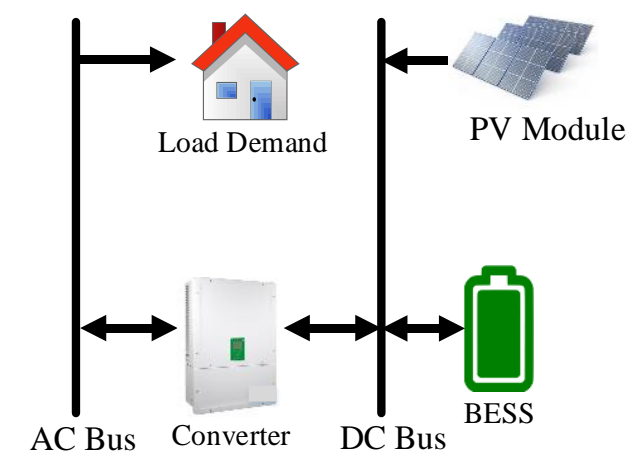

Fig. 7. System configuration for Island operation.

The system is analyzed in HOMER software based on the optimum of the capacity of PV panels in the range of $\mathrm{kW}$ with considering HOMER optimizer variables and economic constrains like interest rate, minimum renewable fraction, capacity shortage, BESS life, available resources which optimized model has been stated in Table 14. In addition, the proposed optimized result contains PV panel in the capacity of $5.58 \mathrm{~kW}$, converter of 2.15 $\mathrm{kW}$. The amount of energy which charges and discharge in BESS throughout the year is 3,099 and $2,785 \mathrm{kWh}$ respectively. The rated power of PV module is $335 \mathrm{~W}$. Thus, the quantity of PV panels would be 17 .

Table 14. Optimized simulation results from HOMER.

\begin{tabular}{|c|c|c|c|c|c|c|c|c|}
\hline \multicolumn{3}{|c|}{ Architecture } & \multicolumn{5}{c|}{ Cost (\$) } & \multicolumn{2}{c|}{ PV module } \\
\hline $\begin{array}{c}\text { PV } \\
\text { module } \\
\text { (quantity) }\end{array}$ & $\begin{array}{c}\text { BESS } \\
\text { (quantity) }\end{array}$ & $\begin{array}{c}\text { Converter } \\
\text { (quantity) }\end{array}$ & NPC & COE & $\begin{array}{c}\text { Operating } \\
\text { cost }\end{array}$ & $\begin{array}{c}\text { Initial } \\
\text { capital }\end{array}$ & $\begin{array}{c}\text { Capital } \\
\text { cost } \\
(\$)\end{array}$ & $\begin{array}{c}\text { Production } \\
\text { (kWh/yr) }\end{array}$ \\
\hline 17 & 6 & 2 & 6,138 & 0.116 & 253.63 & 2,859 & 1,664 & 7,558 \\
\hline
\end{tabular}

Simulation result shows that the AC primary load, excess electricity and unmet electric load are $4106 \mathrm{kWh} / \mathrm{yr}, 2,828 \mathrm{KWh} / \mathrm{yr}$ and $2.91 \mathrm{kWh} / \mathrm{yr}$, respectively. Both The renewable fraction and the power demand supplied by the PV system have been taken $100 \%$ in this case study. The monthly PV power production graph has been represented in Fig.8. The highest amount of PV production belongs to the month of June, because of well PV radiation and temperature and is low in the month of December for the lack of them. 


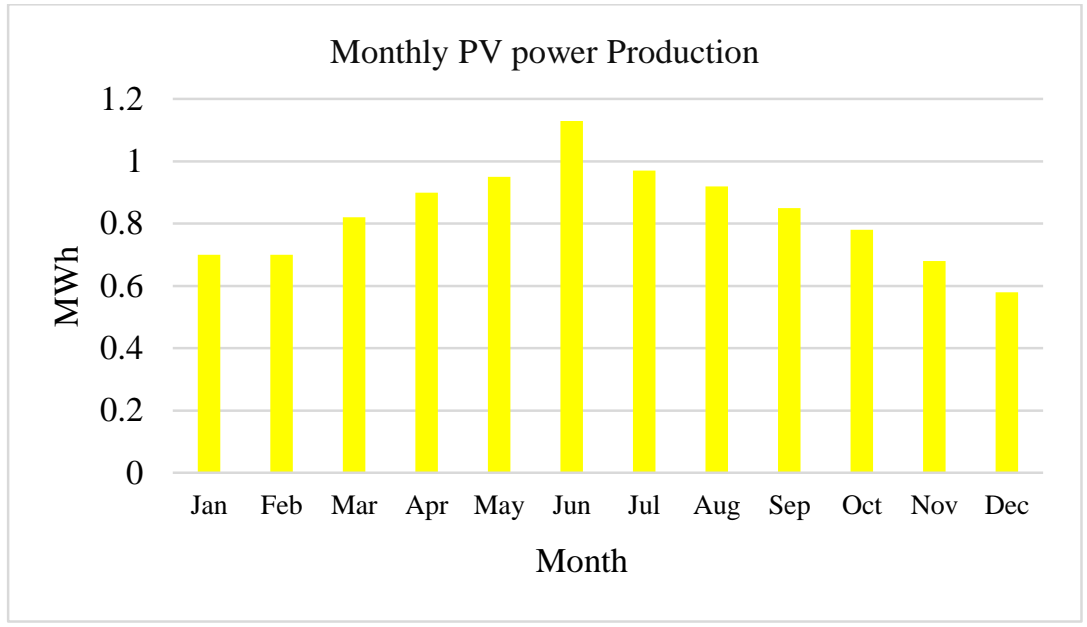

Fig. 8. The monthly average electric power produced by PV system.

Fig.9 shows the relationship between PV panel output and power demand $(\mathrm{kW})$ or BESS's curve of charge and discharge, from 20 to 26 of December for this PV system. Since, it is the worst period in terms of weather condition for a PV panel which the amount of power generation is the lowest throughout the year. It can be seen, whenever the generated power by panel exceeds from the load consumption, the extra power is stored in the BESS. Reversely, when the PV panel efficiency is low due to worse weather condition, the BESS takes the role of supplying load.

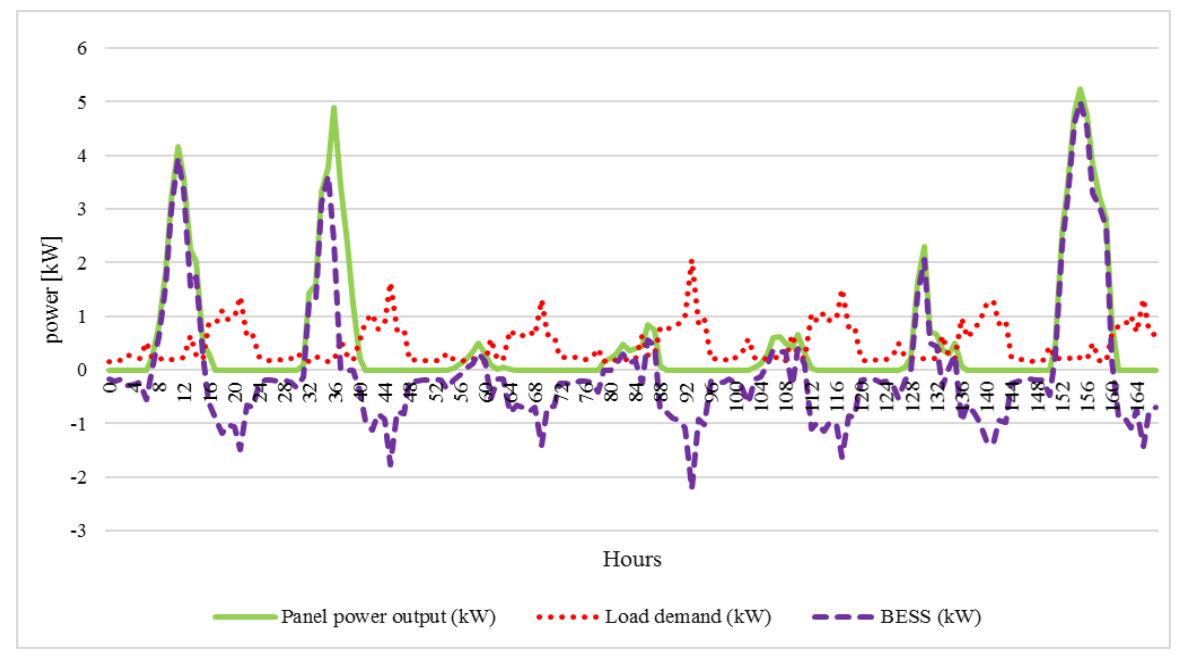

Fig. 9. The operation of PV system in terms of power sources in island mode.

The project lifetime is 25 years and the annual interest rate is taken as $5.88 \%$. No fixed operation and maintenance costs are considered as they are given in the individual components except of PV panels. Annual capacity shortage is set to zero. The NPC summary for each component is given in Table 15. The highest part of the cost is due to the PV panels. 
Table 15. NPC summary of the proposed system.

\begin{tabular}{|c|c|c|c|c|c|}
\hline \multicolumn{7}{|c|}{ NPC according to component (\$) } \\
\hline Component & Capital & Replacement & O \&M & Salvage & Total \\
\hline BESS & 750 & 662.58 & 0 & -89.83 & $1,322.74$ \\
\hline PV panel & $1,664.50$ & 706.20 & $1,793.15$ & -132.91 & $4,030.94$ \\
\hline Converter & 444.80 & 392.96 & 0 & -53.28 & 784.48 \\
\hline System & $2,859.30$ & $1,761.74$ & $1,793.15$ & -276.03 & 6138.17 \\
\hline
\end{tabular}

The main economic output in the PV power plant system in HOMER is the present total net cost that the consumers should be incurred by in implementing the PV power plant system. HOMER calculates this from the data output from simulation and NPC optimization. The total net cost is $\$ 6,138$ with considering the interest rate of $5.88 \%$ during the 25 -year project period. In refer Table. 13, the COE value achieved by HOMER is $\$ 0.116$ per $\mathrm{kWh}$.

The technical results of simulation for each component such as PV panel, converter and BESS has been shown in Table 16.

Table 16. Simulation results for PV system components.

\begin{tabular}{|c|c|c|c|c|c|c|c|}
\hline \multicolumn{2}{|c|}{ PV } & \multicolumn{4}{|c|}{ Converter } & \multicolumn{2}{|c|}{ BESS } \\
\hline Quantity & Value & Quantity & Inverter & Rectifier & Units & Quantity & Value \\
\hline $\begin{array}{c}\text { Rated } \\
\text { Capacity }\end{array}$ & $5.55 \mathrm{~kW}$ & Capacity & 2.22 & 2.06 & $\mathrm{~kW}$ & $\begin{array}{c}\text { Bus } \\
\text { voltage }\end{array}$ & $220 \mathrm{~V}$ \\
\hline $\begin{array}{l}\text { Mean } \\
\text { Output }\end{array}$ & $0.863 \mathrm{~kW}$ & $\begin{array}{l}\text { Energy } \\
\text { In }\end{array}$ & 4,415 & 0 & $\mathrm{kWh} /$ year & $\begin{array}{l}\text { Nominal } \\
\text { Capacity }\end{array}$ & $79.2 \mathrm{kWh}$ \\
\hline $\begin{array}{l}\text { Mean } \\
\text { Output }\end{array}$ & $\begin{array}{c}20.7 \\
\mathrm{kWh} / \mathrm{d}\end{array}$ & $\begin{array}{c}\text { Energy } \\
\text { out }\end{array}$ & 4,106 & 0 & $\mathrm{kWh} /$ year & Energy In & $\begin{array}{c}3,100 \\
\mathrm{kWh} / \text { year }\end{array}$ \\
\hline $\begin{array}{c}\text { Total } \\
\text { Production }\end{array}$ & $\begin{array}{c}7,558 \\
\mathrm{kWh} / \text { year }\end{array}$ & Losses & 309 & 0 & $\mathrm{kWh} /$ year & Energy Out & $\begin{array}{c}2,786 \\
\mathrm{kWh} / \text { year }\end{array}$ \\
\hline $\begin{array}{l}\text { Hours of } \\
\text { Operation }\end{array}$ & $\begin{array}{c}4,386 \\
\text { hrs/year }\end{array}$ & $\begin{array}{l}\text { Hours of } \\
\text { operation }\end{array}$ & 8,752 & 0 & hrs/year & $\begin{array}{l}\text { Lifetime } \\
\text { Throughput }\end{array}$ & $\begin{array}{c}29,530 \\
\mathrm{kWh}\end{array}$ \\
\hline
\end{tabular}

\section{Conclusion}

The aim of this paper is to present the comparative studies for supplying electricity from PV systems both in grid-connected and island mode for a case study in Iran for residential load where sustainable solar resource is accessible. Analysis and simulation have been done 
by HOMER software which obtains best feasible solution for designing the PV systems with considering the electrical and economical aspects. The examination of the results in gridconnected and island mode for PV system with considering different electrical and economical aspects show that the $2 \mathrm{~kW}$ PV panel in grid-connected mode which has been referred in optimal sizing design section is the most feasible scheme design for proposed case. Since, it would be logical to supply load demand from grid-connected PV system instead of island mode due to the economic aspects.

Moreover, the reasonable decision for selecting the PV system in optimal design mode instead of HOMER optimizer in this case of study is that the aim of this paper is paving the way and encouraging consumers for using RES as green energy source due to the lack of accessibility to the fossil fuel resources in future.

\section{References}

1. Lior, N. Energy, (33(6)), pp. (842-857), (2008)

2. Nurunnabi, M. and Roy, N.K., IEEE. (ICAEE). pp. (18-21), (2015).

3. Samimi, J. Solar Energy, 52(5), pp. (401-409), (1994).

4. https://solargis.com/maps-and-gis-data/download/iran

5. Santika, W.G., Sunu, P.W. and Arsawan, BISSTECH. (2015).

6. Duque, E., Ortiz-Grisales, P., Isaza, A., Luján, A., Chica, S. and González-Ruíz, J.D., International Journal of Renewable Energy Research, 8(1), pp. (523-539), (2018).

7. Sepulveda, T.T. and Martinez, L., Int. J. Renew. Energy Res. IJRER, 6(4), pp. (14761481). (2016).

8. Firouzjah, K.G., Renewable and Sustainable Energy Reviews, 94, pp. (267-274), (2018).

9. Ghafoor, A. and Munir, A., Renewable and Sustainable Energy Reviews, 42, pp. (496502), (2015).

10. Hliwa, G.Z. and Bannari, R., (IJRER), 9(3), pp. (1492-1499), (2019).

11. Abul'Wafa, A.R., Electric Power Components and Systems, 45(3), pp. (331-343), (2017).

12. Ahmad, G.E., Renewable Energy,26(3), pp. (379-390), (2002).

13. Barakat, S., Samy, M.M., Eteiba, M.B. and Wahba, W.I., International Journal of Emerging Electric Power Systems, 17(5), pp. (519-528), (2016).

14. Lu, J., Wang, W., Zhang, Y. and Cheng, S., Energies, 10(10), p. (1664), (2017). 
15. Hafez, O. and Bhattacharya, K., Renewable Energy, 45, pp. (7-15), (2012).

16. Bhattacharjee, S. and Dey, A., Sustainable Energy Technologies and Assessments, 7, pp. (6-16), (2014).

17. Hosseini, R.E.Z.A., Soltani, M. and Valizadeh, G., Renewable energy, 30(10), pp. (1541-1555), (2005).

18. Bahramara, S., Moghaddam, M.P. and Haghifam, M.R., A review. Renewable and Sustainable Energy Reviews, 62, pp.609-620. (2016).

19. Spertino, F., Ciocia, A., Di Leo, P., Malgaroli, G. and Russo, A., IntechOpen. (2018).

20. Sen, R. and Bhattacharyya, S.C., Renewable Energy, 62, pp.388-398. (2014).

21. Kim, I. and Harley, R.G., North American Power Symposium (NAPS) (pp. 1-5). (2015). 